\title{
An epidemiological study of blindness in an Indian rural community
}

\author{
R. N. SRIVASTAVA AND B. L. VERMA \\ From the Department of Social and Preventive Medicine, M.L.B. Medical College, Jhansi, Uttar Pradesh
}

SUMMARY A house-to-house survey of blindness in an Indian rural community covering a population of 20134 in 12 villages revealed a prevalence rate of 35 blind and 144 partially blind persons per 10000 population. Blindness was significantly associated with the age, sex, marital status, occupation, and socioeconomic status of the respondents. Caratact, glaucoma, smallpox and trachoma were the main causes of blindness. Preventive measures can reduce the toll of blindness in such a community.

In developing countries higher blindness rates have been observed than in America and Europe (World Health Organisation, 1973a). Recent surveys in India have shown that $1.5 \%$ of the people are blind and over $70 \%$ of blind persons are in the working age groups (Venktaswamy, 1976). As well as the human suffering this causes, there is also a very high economic cost.

In countries like India, the tragedy of blindness is more poignant because preventable infections have spread unchecked, making millions blind. The World Health Organisation expert committee report on the prevention of blindness (1973b) emphasised the need for field studies to identify major local causes of blindness with a view to instituting a campaign to control them. The present rapid study of blindness was undertaken in a rural community of India in order to survey the extent of the problem and its association, if any, with some sociodemographic characteristics of the respondents in the area.

\section{Material and methods}

The study took place at Chirgaon in the area of the Rural Health Training Centre of the Department of Social and Preventive Medicine, M.L.B. Medical College, Jhansi, Uttar Pradesh, during the months of April to September, 1976. It was carried out, under the field supervision of the authors, by teams of medical interns who had previously been given the requisite training at the medical college. Chirgaon had a population of about 70000 in the 1971 census, scattered in 104 villages. Twelve approachable villages within a radius of $12 \mathrm{kms}$ from the headquarters of the health centre at Chirgaon were considered for the study, and a total population of 20134 in these villages was covered in the survey.

The family was the unit of study and every family in the area was visited. During the first and all subsequent visits each member of the family was asked whether he or she had any visual problem or disability of any sort. Those giving suggestive history of any visual difficulty or disability were screened using Snellen's Charts. Infants and preschool children who could not be screened by Snellen's Charts were thoroughly examined for eye conditions ranging from complete loss of one or both eyes to congenital abnormalities, extensive corneal opacity and other conditions suggestive of blindness. Further tests on these children and infants were not performed. Individuals were considered blind if they had distant visual acuity of less than $3 / 60$ in their better eye and partially blind if they had visual acuity of $3 / 60$ or less in their worse eye (World Health Organisation, 1973b).

Causes of blindness were identified retrospectively by taking a past history from the respondents and by careful examination of the eyes. The relevant information for each individual was recorded on a pre-tested schedule designed for the purpose. Sociodemographic characteristics of the total population of the area were obtained from a baseline survey conducted a few months earlier by the staff of the department. Social status was categorised according to monthly per capita income, as suggested by Prasad (1968). 


\section{Results}

\section{CAUSES OF BLINDNESS}

Table 1 shows the distribution of blind and partially blind people according to the causes of blindness. The major causes of blindness were cataract $(32.4 \%)$, followed by glaucoma ( $25.4 \%)$, smallpox $(18 \cdot 3 \%)$, trachoma $(8 \cdot 5 \%)$, other infectious diseases $(7 \cdot 1 \%)$, and congenital abnormalities $(5 \cdot 6 \%)$. The major causes of partial blindness were cataract $(58 \cdot 1 \%)$, smallpox $(15 \cdot 2 \%)$, injuries $(8 \cdot 7 \%)$, trachoma $(8.0 \%)$, and glaucoma $(3.8 \%)$.

\section{AGE, SEX AND BLINDNESS}

Table 2 gives the age-specific prevalence rates for men of blindness, partial blindness, and both conditions. Table 3 gives the results for women. In both sexes, the prevalence rates of either condition increased with age (Fig. 1). But the observed trends with age appear to differ between the sexes; women tend to have lower rates under the age of $\mathbf{5 0}$ and higher rates in the older age groups. At the age of 75 and over, the sex difference is highly significant $(\mathrm{P}<\cdot 005) ; 11$ of the 59 males $(18 \cdot 6 \%)$ are either blind or partially blind compared with 19 of the 33 females $(57.6 \%)$.

The overall prevalence rate of blindness (all ages and both sexes) and of partial blindness are 35 and $144 / 10000$ respectively. As these overall rates are age and sex dependent (Fig. 1), the comparisons in other groups need appropriate adjustments.

MARITAL STATUS AND BLINDNESS

Table 4 gives the age-specific prevalence rates of blindness and partial blindness in three groups. The overall prevalence in the unmarried group

Table 1 Distribution of blind and partially blind by causes of blindness

\begin{tabular}{|c|c|c|c|c|c|c|c|}
\hline \multirow{2}{*}{ Causes } & \multicolumn{2}{|c|}{ Blind } & \multicolumn{2}{|c|}{ Partially blind } & \multicolumn{3}{|c|}{ Blind and partially blind } \\
\hline & No. & $\%$ & No. & $\%$ & No. & $\%$ & \\
\hline $\begin{array}{l}\text { Cataract } \\
\text { Glaucoma } \\
\text { Smallpox } \\
\text { Trachoma } \\
\text { Other infectious diseases } \\
\text { Congenital abnormalities } \\
\text { Injury to eye } \\
\text { Others }\end{array}$ & $\begin{array}{r}23 \\
18 \\
13 \\
6 \\
5 \\
4 \\
1 \\
1\end{array}$ & $\begin{array}{l}(32) \\
(25) \\
(18) \\
(9) \\
(7) \\
(6) \\
(1) \\
(1)\end{array}$ & $\begin{array}{r}168 \\
11 \\
44 \\
23 \\
9 \\
6 \\
25 \\
3\end{array}$ & $\begin{array}{l}\text { (58) } \\
\text { (4) } \\
\text { (15) } \\
\text { (8) } \\
(3) \\
(2) \\
\text { (9) } \\
\text { (1) }\end{array}$ & $\begin{array}{r}191 \\
29 \\
57 \\
29 \\
14 \\
10 \\
26 \\
4\end{array}$ & $\begin{array}{l}(53) \\
(8) \\
(16) \\
(8) \\
(4) \\
(3) \\
(7) \\
(1)\end{array}$ & 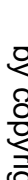 \\
\hline All causes & 71 & $100 \cdot 00$ & 289 & $100 \cdot 00$ & 360 & $100 \cdot 00$ & 光 \\
\hline
\end{tabular}

Table 2 Age distribution of blindness and partial blindness in males

\begin{tabular}{|c|c|c|c|c|c|c|c|}
\hline \multirow[b]{2}{*}{ Age } & \multirow{2}{*}{$\begin{array}{l}\text { Population } \\
\text { surveyed }\end{array}$} & \multicolumn{2}{|c|}{ Blind } & \multicolumn{2}{|c|}{ Partially blind } & \multicolumn{2}{|c|}{ Blind and partially blina } \\
\hline & & No. & $\begin{array}{l}\text { Prevalence } \\
\text { per } 10000\end{array}$ & No. & $\begin{array}{l}\text { Prevalence } \\
\text { per } 10000\end{array}$ & No. & $\begin{array}{l}\text { Prevalence } \\
\text { per } 10000\end{array}$ \\
\hline $\begin{array}{l}\text { Under } 1 \text { year } \\
1-4 \\
5-14 \\
15-24 \\
25-34 \\
35-44 \\
45-54 \\
55-64 \\
65-74 \\
75 \text { and over }\end{array}$ & $\begin{array}{r}92 \\
1290 \\
2874 \\
1589 \\
1561 \\
1326 \\
933 \\
735 \\
297 \\
59\end{array}$ & $\begin{array}{l}- \\
\\
5 \\
7 \\
2 \\
3 \\
7 \\
5 \\
3\end{array}$ & $\begin{array}{r}- \\
\overline{31} \\
45 \\
15 \\
32 \\
95 \\
168 \\
508\end{array}$ & $\begin{array}{r}2 \\
8 \\
11 \\
9 \\
18 \\
20 \\
43 \\
35 \\
8\end{array}$ & $\begin{array}{r}-15 \\
15 \\
28 \\
69 \\
58 \\
136 \\
214 \\
585 \\
1178 \\
1356\end{array}$ & $\begin{array}{r}-2 \\
8 \\
16 \\
16 \\
20 \\
23 \\
50 \\
40 \\
11\end{array}$ & $\begin{array}{r}\overline{15} \\
28 \\
101 \\
103 \\
151 \\
246 \\
680 \\
1347 \\
1864\end{array}$ \\
\hline All & 10756 & 32 & 30 & 154 & 143 & 186 & 173 \\
\hline
\end{tabular}

Table 3 Age distribution of blindness and partial blindness in females

\begin{tabular}{|c|c|c|c|c|c|c|c|}
\hline \multirow[b]{2}{*}{ Age } & \multirow{2}{*}{$\begin{array}{l}\text { Population } \\
\text { surveyed }\end{array}$} & \multicolumn{2}{|c|}{ Blind } & \multicolumn{2}{|c|}{ Partially blind } & \multicolumn{2}{|c|}{ Blind and partially blina } \\
\hline & & No. & $\begin{array}{l}\text { Prevalence } \\
\text { per } 10000\end{array}$ & No. & $\begin{array}{l}\text { Prevalence } \\
\text { per } 10000\end{array}$ & No. & $\begin{array}{l}\text { Prevalence } \\
\text { per } 10000\end{array}$ \\
\hline $\begin{array}{l}\text { Under } 1 \text { year } \\
1-4 \\
5-14 \\
15-24 \\
25-34 \\
35-44 \\
45-54 \\
55-64 \\
65-74 \\
75 \text { and over }\end{array}$ & $\begin{array}{r}89 \\
1209 \\
2268 \\
1427 \\
1506 \\
1120 \\
834 \\
614 \\
278 \\
33\end{array}$ & $\begin{array}{r}- \\
2 \\
1 \\
3 \\
3 \\
4 \\
9 \\
12 \\
5\end{array}$ & $\begin{array}{r}- \\
9 \\
7 \\
20 \\
27 \\
48 \\
147 \\
432 \\
1515\end{array}$ & $\begin{array}{r}-1 \\
3 \\
2 \\
4 \\
4 \\
20 \\
45 \\
42 \\
14\end{array}$ & $\begin{array}{r}-8 \\
13 \\
14 \\
27 \\
36 \\
240 \\
733 \\
1511 \\
4242\end{array}$ & $\begin{array}{r}-1 \\
5 \\
3 \\
7 \\
7 \\
24 \\
54 \\
54 \\
19\end{array}$ & \begin{tabular}{r|}
8 \\
22 \\
21 \\
46 \\
63 \\
288 \\
879 \\
1942 \\
5758
\end{tabular} \\
\hline All & 9378 & 39 & 42 & 135 & 144 & 174 & 186 \\
\hline
\end{tabular}




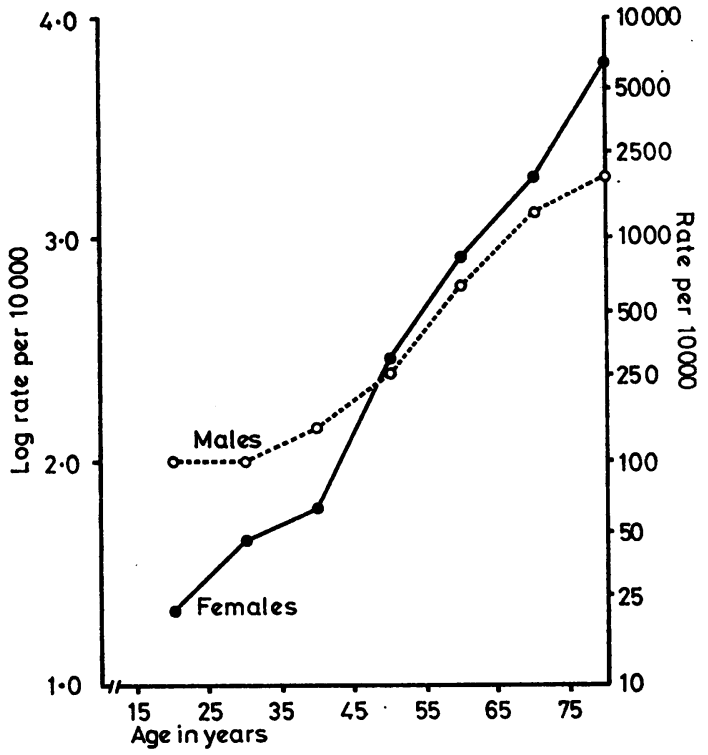

Fig. 1 Prevalence of blindness and partial blindness by age and gender.

$(52 / 10000)$ is lower than in the married group $(184 / 10000)$ but this comparison is misleading because of the differences in the age distribution of the two groups (Fig. 2).

For each age group in the marriageable age range, the unmarried have much higher prevalence rates than the married. It is noteworthy that 8 of the 10 unmarried persons aged 35 or over were either blind or partially blind. Marriage is almost universal in India, and such high prevalence rates imply that blindness is a barrier to marriage. The age-specific prevalence rates were considerably higher for widows and widowers, and considerably higher for separated than for married persons.

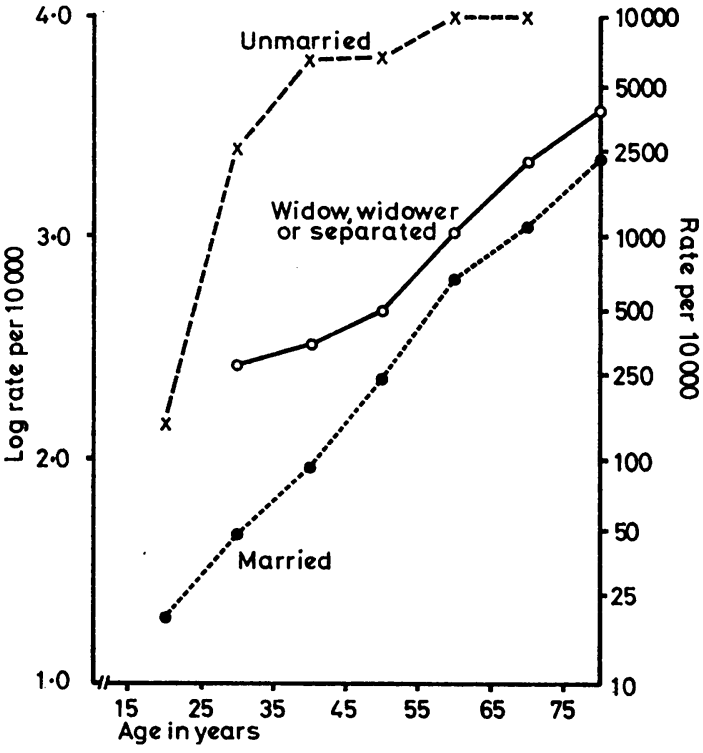

Fig. 2 Prevalence of blindness and partial blindness by marital status.

\section{OCCUPATION AND BLINDNESS}

Prevalence rates of blindness by occupation are given in Table 5. Prevalence rates per 10000 range from 43 (34 out of 7931) in students and children, to 4545 ( 5 out of 11) in beggars. The rates in Table 5 are unadjusted for age and sex. But the much higher rates in beggars, artisans and businessmen are particularly noteworthy.

\section{Discussion}

The results of the present study are difficult to compare with other studies because work on the subject is scanty, especially for the type of population

Table 4 Age distribution of blind and partially blind by marital status

\begin{tabular}{|c|c|c|c|c|c|c|c|c|c|}
\hline \multirow[b]{2}{*}{ Age } & \multicolumn{3}{|l|}{ Unmarried } & \multicolumn{3}{|l|}{ Married } & \multicolumn{3}{|c|}{ Widow/Widower/Separated } \\
\hline & Population & No. & $\begin{array}{l}\text { Prevalence } \\
\text { per } 10000\end{array}$ & Population & No. & $\begin{array}{l}\text { Prevalence } \\
\text { per } 10000\end{array}$ & Population & No. & $\begin{array}{l}\text { Prevalence } \\
\text { per } 10000\end{array}$ \\
\hline $\begin{array}{l}\text { Under } 1 \text { year } \\
1-4 \\
5-14 \\
15-24 \\
25-34 \\
35-44 \\
45-54 \\
55-64 \\
65-74 \\
75 \text { and over }\end{array}$ & $\begin{array}{r}181 \\
2499 \\
5093 \\
949 \\
32 \\
3 \\
3 \\
2 \\
2 \\
\end{array}$ & $\begin{array}{r}3 \\
12 \\
15 \\
8 \\
2 \\
2 \\
2 \\
2 \\
-\end{array}$ & $\begin{array}{c}\overline{12 *} \\
24 \\
158 \\
2500^{*} \\
6666^{*} \\
6666^{*} \\
10000^{*} \\
10000^{*} \\
-\end{array}$ & $\begin{array}{rr} & - \\
& 49 \\
2 & 057 \\
2 & 997 \\
2 & 354 \\
1 & 553 \\
1 & 019 \\
327 \\
38\end{array}$ & $\begin{array}{r}- \\
1 \\
4 \\
14 \\
22 \\
35 \\
68 \\
38 \\
9\end{array}$ & $\begin{array}{c}- \\
204^{*} \\
19^{*} \\
47 \\
93 \\
225 \\
667 \\
1162 \\
2368\end{array}$ & $\begin{array}{r}\overline{-} \\
\overline{1} \\
38 \\
89 \\
211 \\
328 \\
246 \\
54\end{array}$ & $\begin{array}{r}- \\
\bar{Z} \\
\overline{1} \\
3 \\
10 \\
34 \\
54 \\
21\end{array}$ & $\begin{array}{r}- \\
\overline{-} \\
0 \\
263 \\
337 \\
474 \\
1037 \\
2195 \\
3889\end{array}$ \\
\hline Total & 8764 & 46 & 52 & 10394 & 191 & 184 & 976 & 123 & 1260 \\
\hline
\end{tabular}

*Figures based on less than five observations 
Table 5 Distribution of blind and partially blind by occupation

\begin{tabular}{|c|c|c|c|c|c|c|c|}
\hline \multirow[b]{2}{*}{ Occupation } & \multirow{2}{*}{$\begin{array}{l}\text { Population } \\
\text { surveyed }\end{array}$} & \multicolumn{2}{|c|}{ Blind } & \multicolumn{2}{|c|}{ Partially blind } & \multicolumn{2}{|c|}{ Blind and partially blind } \\
\hline & & No. & $\begin{array}{l}\text { Prevalence } \\
\text { per } 10000\end{array}$ & No. & $\begin{array}{l}\text { Prevalence } \\
\text { per } 10000\end{array}$ & No. & $\begin{array}{l}\text { Prevalence } \\
\text { per } 10000\end{array}$ \\
\hline $\begin{array}{l}\text { Beggars } \\
\text { Artisans } \\
\text { Household/housewives } \\
\text { Businessmen } \\
\text { Servicemen } \\
\text { Labourers } \\
\text { Farmers } \\
\text { Students/children }\end{array}$ & $\begin{array}{r}11 \\
101 \\
6114 \\
86 \\
374 \\
1347 \\
4170 \\
7931\end{array}$ & $\begin{array}{r}3 \\
2 \\
46 \\
2 \\
1 \\
1 \\
16\end{array}$ & $\begin{array}{r}2727 \\
198 \\
75 \\
53 \\
7 \\
2 \\
20\end{array}$ & $\begin{array}{r}2 \\
17 \\
73 \\
13 \\
11 \\
41 \\
114 \\
18\end{array}$ & $\begin{array}{r}1818 \\
1683 \\
119 \\
1512 \\
294 \\
304 \\
273 \\
23\end{array}$ & $\begin{array}{r}5 \\
19 \\
119 \\
13 \\
13 \\
42 \\
115 \\
34\end{array}$ & $\begin{array}{r}4545 \\
1881 \\
195 \\
1512 \\
348 \\
312 \\
276 \\
43\end{array}$ \\
\hline Total & 20134 & 71 & 35 & 289 & 144 & 360 & 178 \\
\hline
\end{tabular}

Table 6 Distribution of blind and partially blind by social status

\begin{tabular}{|c|c|c|c|c|c|c|c|}
\hline \multirow[b]{2}{*}{ Social class* } & \multirow{2}{*}{$\begin{array}{l}\text { Population } \\
\text { surveyed }\end{array}$} & \multicolumn{2}{|c|}{ Blind } & \multicolumn{2}{|c|}{ Partially blind } & \multicolumn{2}{|c|}{ Blind and partially blind } \\
\hline & & No. & $\begin{array}{l}\text { Prevalence } \\
\text { per } 10000\end{array}$ & No. & $\begin{array}{l}\text { Prevalence } \\
\text { per } 10000\end{array}$ & No. & $\begin{array}{l}\text { Prevalence } \\
\text { per } 10000\end{array}$ \\
\hline$\underset{\text { III }}{\text { III }}$ & $\begin{array}{r}312 \\
1091 \\
10054 \\
8677\end{array}$ & $\begin{array}{r}-5 \\
40 \\
26\end{array}$ & $\begin{array}{l}\overline{46} \\
40 \\
30\end{array}$ & $\begin{array}{r}3 \\
17 \\
178 \\
91\end{array}$ & $\begin{array}{r}96 \\
156 \\
177 \\
105\end{array}$ & $\begin{array}{r}3 \\
22 \\
218 \\
117\end{array}$ & $\begin{array}{r}96 \\
202 \\
217 \\
135\end{array}$ \\
\hline Total & 20134 & 71 & 35 & 289 & 144 & 360 & 178 \\
\hline
\end{tabular}

* None of the respondents belonged to Social class I

considered here. Varied definitions of blindness and visual impairment put forward in different surveys also make comparisons difficult. However, the prevalence rates detected in this study may be compared, if not strictly, with some others recorded.

Our present study revealed 179 blind or partially blind persons per 10000 population. Chakrabarti et al. (1974), in a survey of another rural community in the same state, observed a rate of 570/10000 blind or partially blind. In another survey, undertaken in 78 villages of Banki community development block of Barabanki District, Uttar Pradesh, (Prasad and Jain, 1971), a rate of 27/10 000 blind persons was observed against $35 / 10000$ in the present study. These differences are probably due to the varied definitions of blindness considered in the two surveys. Prevalence rates of blindness in developed countries of America and Europe have been observed in general to be about 20/10000 population, although these rates are considerably higher in less developed countries of Asia and Africa (World Health Organisation, 1973b).

The progressive increase with age in prevalence rates of blindness and partial blindness for both males and females was statistically highly significant (Fig. 1). It was probably due to the heavy burden of blindness and partial blindness caused by cataract and glaucoma, the diseases of the older age groups. Another important finding was that there were only three children in the preschool age-group with severely impaired vision (partially blind) and no blind child under five years of age was discovered. This may be taken to indicate a healthy trend towards reduced blindness in the area; the progressively improved control of smallpox for a few years before its final eradication from India might be one of the major factors contributing to this trend.

Our study also revealed that the prevalence of blindness was sex dependent (Fig. 1.). The relative higher rates of prevalence in males under the age of $\infty$ 50 than in females could have been due to the fact 0 that men in this age-group generally work out of doors and are therefore more exposed to the risk of eye injuries and infections. Similarly, higher rates of blindness in females than in males in the older age- $\mathbb{D}$ groups might be due to the cumulative effect of $\vec{F}$ irritating conditions like kitchen smoke to which women in the rural areas of India are more exposed than men.

Higher age-specific prevalence rates of blindness for unmarried persons of marriageable age were probably due, as discussed earlier, to the fact that such persons could not get married because they were blind. The reasons for higher rates of blindness in widows, widowers and separated persons than in married persons need to be studied in a more detailed investigation. It is reasonable to assume that blindness can cause some couples to separate. It $\frac{D}{O}$ would be interesting to discover whether bereavement may sometimes lead to impairment of vision $\tilde{N}$ in widows and widowers.

Occupation also had a significant bearing on $N$ blindness (Table 5). The highest prevalence was $\omega$ observed among beggars, presumably because they became beggars as a result of being blind. Their 0 blindness in turn was probably due to poor socio- 
economic status, unawareness of medical facilities, and illiteracy, among other factors. However, this probability could not be studied in detail because of the small number of beggars in the survey. A relatively high prevalence of partial blindness among businessmen might be due to the difficulties experienced by some in obtaining suitable jobs after partial loss of eyesight, so that in order to survive, they set up as small, self-employed businessmen in the villages. Persons engaged in skilled professions (artisans), including carpenters, goldsmiths, potters and masons, were at a relatively higher risk from injuries and infections and this was probably why their prevalence rates were also higher. However, the reasons need further investigation, especially since these rates were not age and sex adjusted, so a precise comparison could not be made.

A significant association of blindness with social status (Table 6) was also observed, although an exact comparison could not be made because the prevalence rates in respect of social status were not adjusted for age and sex. These rates were higher for people in Social Classes III and IV than for those in Social Class II. It was also interesting to note that the prevalence of blindness in Social Class V was lower than in Social Classes III and IV. This probably suggests that, on average, people in the lowest social group with this disability did not live long enough to reach the higher rates of older agegroups. The study at Banki community development block of Barabanki District, Uttar Pradesh (Prasad and Jain, 1968) also revealed an increasing prevalence of blindness with decreasing social status.

Established major causes of blindness such as cataract, smallpox, trachoma and glaucoma (Table 1) were also found in the present study. In order to reduce the load of blindness in the community, efforts should be made to improve medical facilities as much as possible. This could be done by organising eye camps and starting eye clinics in the sub-divisional hospitals at least, and by setting up primary health centres to treat cataract cases and to test whether a periodical check-up for early detection of serious disease like glaucoma and trachoma would reduce the incidence of blindness. People also need to be educated about the seriousness of such diseases and taught to utilise the medical facilities available. No doubt the elimination of smallpox from India will considerably reduce the load of blindness in the community. Even so, improvements are needed in nutrition, in the control and early treatment of infections, and in the safety of roads, workplaces and homes in order to lighten the burden of blindness in the community.

We thank Sri R. S. Chauhan, Health Educator in the Department of Social and Preventive Medicine, M.L.B. Medical College, Jhansi, Uttar Pradesh, and the teams of medical interns trained in the department for their valuable co-operation during this study. The authors also thank the reviewer for helpful suggestions.

Reprints from R. N. Srivastava, Department of Social and Preventive Medicine, M.L.B. Medical College, Jhansi, Uttar Pradesh, India.

\section{References}

Chakrabarti, J., Garg, A. C., and Siddhu, C. M. S. (1974). Prevalence and pattern of blindness in the field practice area of a rural health training centre. Indian Journal of Ophthalmology, 22, 3, 4-8.

Prasad, B. G. (1968). Social classification. Journal of the Indian Medical Association, 51, 365-366.

Prasad, B. G., and Jain, V. C. (1971). Blindness, In A Text Book of Preventive and Social Medicine, first edition, pp. 334-337. Edited by S. C. Seal. Allied Agencies: Calcutta.

Venktaswamy, G. (1976). Eye diseases can be prevented. Swasthya Hind, 20, 4, 106-108.

World Health Organisation (1973a). Prevention of blindness. WHO Chronicle, 27, 1, 21.

World Health Organisation Expert Committee (1973b). The Prevention of Blindness. Technical Report Series No. 518, pp. 6-10. WHO: Geneva. 